\title{
Cebocephaly, alobar holoprosencephaly, spina bifida, and sirenomelia in a stillbirth
}

\author{
Chih-Ping Chen, Shin-Lin Shih, Fen-Fen Liu, Sheau-Wen Jan
}

\begin{abstract}
Cebocephaly and sirenomelia are uncommon birth defects. Their association is extremely rare; however, the presence of spina bifida with both conditions is not unexpected. We report on a female stillbirth with cebocephaly, alobar holoprosencephaly, cleft palate, lumbar spina bifida, sirenomelia, a single umbilical artery, and a 46,XX karyotype, but without maternal diabetes mellitus. Our case adds to the examples of overlapping cephalic and caudal defects, possibly related to vulnerability of the midline developmental field or axial mesodermal dysplasia spectrum.

(F Med Genet 1997;34:252-255)
\end{abstract}

Keywords: holoprosencephaly; cebocephaly; sirenomelia; spina bifida.

\section{Department of}

Gynaecology, Mackay

Memorial Hospital, 92,

Section 2, Chung-Shan

North Road, Taipei,

Taiwan, Republic of

China

C-P Chen

Department of Radiology, Mackay

Memorial Hospital, 92,

Section 2, Chung-Shan

North Road, Taipei,

Taiwan, Republic of

China

S-L Shih

\section{Department of}

Medical Research,

Mackay Memorial

Hospital, 92, Section 2,

Chung-Shan North

Road, Taipei, Taiwan,

Republic of China

C-P Chen

F-F Liu

S-W Jan

Correspondence to:

Dr Chen.

Received 4 July 1996

Revised version accepted for publication 18 October 1996
Sirenomelia and holoprosencephaly are well defined congenital malformations that usually occur independently. Sirenomelia, a severe form of caudal defect with an incidence of 1.54.2 per 100000 births, ${ }^{1}$ is characterised by complete or incomplete fusion of the lower extremities. Various skeletal and podalic presentations of sirenomelia have been described. ${ }^{2}$ There is a $100-150$ fold increase in the incidence of sirenomelia in monozygotic twins over that in singletons and dizygotic twins. ${ }^{1}$ The absence of chromosomal abnormalities and familial inheritance has been noted in almost all cases of sirenomelia. Administration of retinoic acid $^{3}$ and cyclophosphamide ${ }^{4}$ to pregnant mice and hamsters, and destroying the axial portion of the caudal mesoderm of chicken embryos, ${ }^{5}$ have been reported to produce limb defects including sirenomelia. About $2 \%$ of sirenomelia cases are associated with maternal diabetes mellitus. ${ }^{6}$ Common associated abnormalities include hemivertebrae, spina bifida, meningocele, deformed pelvis, a single umbilical artery, abnormal internal and external genitalia, urinary tract anomalies, imperforate anus, pulmonary hypoplasia, tracheo-oesophageal fistula, and cardiovascular malformation. ${ }^{1}$ Central nervous system (CNS) anomalies (table 1) present in less than $10 \%$ of patients with sirenomelia.
Holoprosencephaly (HPE), a severe form of cephalic defect with an incidence of 0.63 in 10000 live births with normal chromosomes, ${ }^{23}$ is characterised by an anomalous craniofacial complex that involves a series of forebrain and midface malformations of graded severity. ${ }^{24}$ HPE is associated with teratogenic and genetic factors. Alcohol and maternal diabetes are known teratogenic factors. There is a 200 -fold increase in the incidence of holoprosencephaly in infants of diabetic mothers over infants of non-diabetic mothers. ${ }^{25}$ Animal models involving the ingestion of the plant Veratum californicum, which contains steroidal alkaloids, can produce cyclopia in sheep embryos. ${ }^{26}$ Cytogenetic abnormalities have been reported in 50\% of all HPE patients and the specific chromosome aberrations include trisomy 13, trisomy 18, triploidy, del(13q), dup(13q), del(18p), $\operatorname{del}(7)(\mathrm{q} 36), \operatorname{dup}(3)(\mathrm{p} 24-\mathrm{pter}), \operatorname{del}(2)(\mathrm{p} 21)$ and $\operatorname{del}(21)(\mathrm{q} 22.3){ }^{25}$ At the Human Gene Mapping 11 Conference, ${ }^{27}$ four putative HPE genes were designated: HPE on chromosome $21 \mathrm{q} 22.3$, HPE2 on $2 \mathrm{p} 21, \mathrm{HPE} 3$ on $7 \mathrm{q} 36$-qter, and HPE 4 on 18pter-q11. Familial HPE with a normal karyotype has been described with autosomal dominant, recessive, and $\mathrm{X}$ linked

Table 1 Summary of previously reported cases of CNS abnormalities associated with sirenomelia

\begin{tabular}{|c|c|}
\hline References & CNS abnormalities associated with sirenomelia \\
\hline 7 & Craniorachischisis totalis (case report) \\
\hline 8 & Craniorachischisis totalis (case report) \\
\hline 9 & Anencephaly (case report) \\
\hline 10 & $\begin{array}{l}\text { Meningomyelocele, hydrocephalus and } \\
\text { Arnold-Chiari malformation }(1 / 11)\end{array}$ \\
\hline 11 & Atelencephaly and cebocephaly (case report) \\
\hline 12 & Hydrocephalus $(2 / 3)$ \\
\hline 2 & $\begin{array}{l}\text { Hydrocephalus ( } 2 / 77) \text {, hydrocephalus and } \\
\text { meningomyelocele }(1 / 77) \text {, Arnold-Chiari } \\
\text { malformation, absent corpus callosum, and } \\
\text { lumbar meningomyelocele }(1 / 77)\end{array}$ \\
\hline 13 & $\begin{array}{l}\text { Anencephaly and cervicothoracic } \\
\text { meningomyelocele (case report) }\end{array}$ \\
\hline 14 & $\begin{array}{l}\text { Hydrocephalus }(1 / 11) ; \text { spina bifida occulta } \\
(1 / 11) ; \text { spina bifida with meningocele }(1 / 11)\end{array}$ \\
\hline 15 & $\begin{array}{l}\text { Myelomeningocele, hydrocephalus, and others } \\
(5 / 54)\end{array}$ \\
\hline 16 & Anencephaly (case report) \\
\hline 17 & Meningocele (case report) \\
\hline 18 & $\begin{array}{l}\text { Neural tube defects }(7 / 98) \text { ( } 6 \text { low spina bifida, } 1 \\
\text { cervical spina bifida); hydrocephalus }(2 / 98) \text {; } \\
\text { cyclopia (1/98) }\end{array}$ \\
\hline 19 & Craniorachischisis totalis (case report) \\
\hline 20 & $4 / 101^{\star}$ \\
\hline 6 & Meningomyelocele (1/4) \\
\hline 21 & Cervicothoracic spina bifida (case report) \\
\hline 22 & $\begin{array}{l}\text { Thoracolumbar meningomyelocele and } \\
\text { Arnold-Chiari malformation (case report) }\end{array}$ \\
\hline $\begin{array}{l}\text { Present } \\
\text { case }\end{array}$ & $\begin{array}{l}\text { Cebocephaly, alobar holoprosencephaly, and } \\
\text { lumbar spina bifida (case report) }\end{array}$ \\
\hline
\end{tabular}

^Nature of CNS abnormalities not reported. 


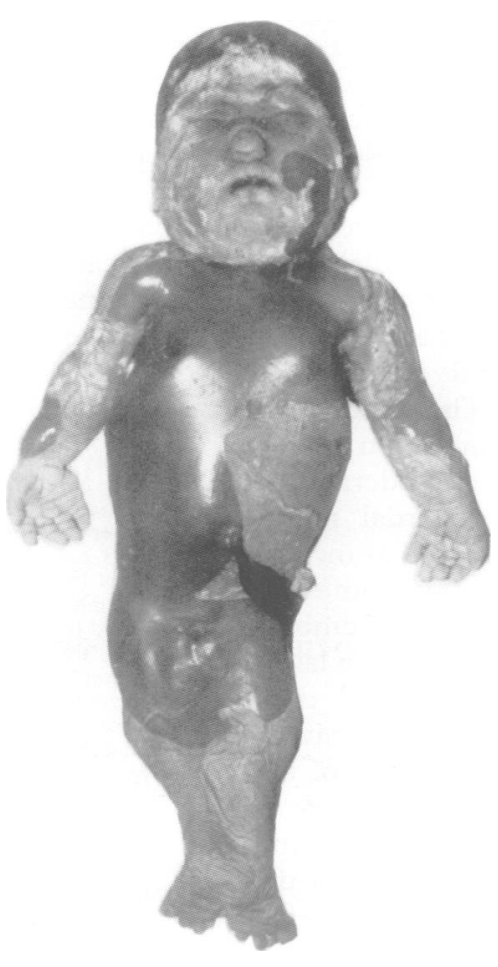

Figure 1 Photograph of the sireniform stillbirth showing cebocephaly with ocular hypotelorism and a single nostril. The lower limbs are fused from the pelvis to the ankles and angulated $180^{\circ}$ posteriorly in relation to the trunk.

inheritance. ${ }^{28} 29 \mathrm{HPE}$ has also been associated with Martin syndrome, Steinfeld syndrome, CHARGE association, Meckel-Gruber syndrome, Kallmann syndrome, Hall-Pallister syndrome, and Vasadi syndrome. ${ }^{25}{ }^{30}$ Common associated abnormalities include microcephaly, undivided thalamus, agenesis of the corpus callosum, arhinencephaly, renal cysts and dysplasia, omphalocele, cardiovascular malformations, club foot, myelomeningocele, and intestinal abnormalities. ${ }^{31}$
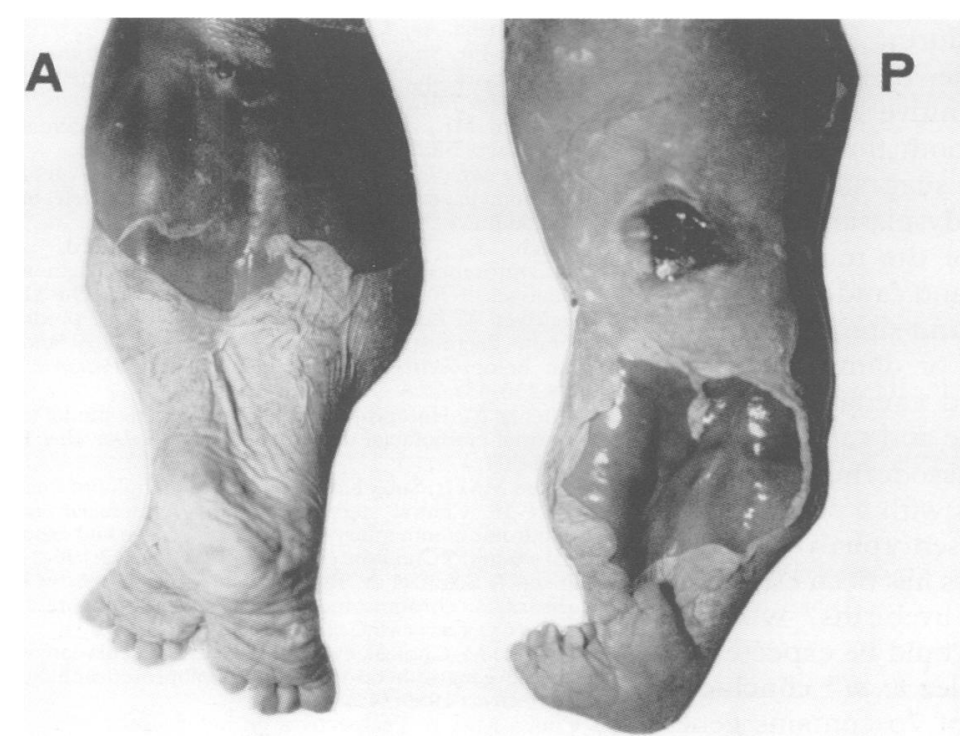

Figure 2 (Left) Anterior view of the lower limbs showing the popliteal fossae and heels pointing forwards. (Right) Posterior view of the lower limbs and the trunk shows lumbar spina bifida, and the knees and toes pointing backwards. No external genitalia or anus are visible.
The association of holoprosencephaly and sirenomelia is extremely rare. In 1986, Young et $a l^{11}$ first reported a twin infant, born at 33 gestational weeks, with cebocephaly, atelencephaly, and sirenomelia. Subsequently, only one patient with cyclopia, holoprosencephaly, and sirenomelia has been observed. ${ }^{18}$ Here, we report an additional case of holoprosencephaly with sirenomelia. To our knowledge, the combination of cebocephaly, alobar holoprosencephaly, cleft palate, spina bifida, and sirenomelia has not been previously reported.

\section{Case report}

The proband was stillborn at 28 weeks' gestation with a weight of $1500 \mathrm{~g}$ and a length of $38 \mathrm{~cm}$. She was the second child of a 25 year old woman. The parents are Chinese, nonconsanguineous, and healthy. There was no family history of diabetes mellitus, twins, or congenital malformations. Maternal urine throughout the pregnancy did not contain glucose. The mother had one healthy 2 year old child. She denied any exposure to drugs for ovulation before conception, or alcohol, teratogenic medication, irradiation, or infectious diseases during this pregnancy. Her pregnancy with this child was uneventful except that oligohydramnios was noted during the second trimester. At 28 weeks' gestation, ultrasonography indicated intrauterine fetal death.

Physical examination of the stillbirth showed microcephaly, ocular hypotelorism, a single nostril, cebocephaly (fig 1), malformed, low set ears, and cleft palate. Detailed evaluation showed soft tissue fusion of the lower limbs from the pelvis to the ankles. The feet were normally formed and fused at the heels. The fused lower limbs were angulated $180^{\circ}$ posteriorly in relation to the trunk (fig 1). Both knees and toes pointed backwards. There was imperforate anus, spina bifida over the lumbar area, and absence of external genitalia (fig 2). The umbilical cord contained only a single umbilical artery and an umbilical vein. Radiographs showed two femora, two tibiae, two fibulae, incomplete rotation of the legs leading to a medial position of the fibulae, thin ribs, hypoplastic vertebrae, dextroscoliosis of the thoracolumbar spine, sacral agenesis, and poorly formed acetabula. Necropsy showed alobar holoprosencephaly with a single ventricle and spina bifida occulta over the lumbar area. Data on the internal organs were not available because of severe calcification and autolysis of the tissue. A cytogenetic study was performed on Giemsa banded chromosomes from cultured chorionic villi cells and showed a normal 46,XX karyotype.

\section{Discussion}

Our case is a rare combination of type I sirenomelia ${ }^{1}$ with sympus dipus, alobar holoprosencephaly, cebocephaly, and spina bifida, without the association of maternal diabetes mellitus, monozygotic twins, abnormal chromosomal complements, or familial inheritance. 
In 1989, O'Rahilly and Müller ${ }^{32}$ and in 1992, Källén et $a l^{18}$ suggested that cyclopia and sirenomelia have a similar mode of formation and both may share similar aetiological and pathogenetic factors affecting the development of the axial mesoderm. In holoprosencephaly, deficiency of prechordal mesoderm occurs at or before 4 weeks of embryonic age. During the third week of embryonic life, the prechordal mesoderm migrates forwards into the area anterior to the notochord and evolves into midline facial development. The prechordal mesoderm plays a reciprocal induction role in the morphogenesis of the neurectoderm, the forebrain. Deficiencies of prechordal mesoderm cause midfacial defects as well as incomplete forebrain development. ${ }^{33}{ }^{34}$ Sirenomelia is believed to originate before 30 days of embryonic life and to occur through a failure in lateralisation secondary to a mesenchymal deficiency of the caudal eminence. ${ }^{32}$ The caudal eminence contributes to the formation of the notochord, vertebrae, lower limb buds, perineum, neural plate, neural cord, hindgut, and blood vessels. An extensive disturbance of the axial mesoderm can cause concomitant alteration of neural ectoderm, and consequently neural tube defects occur. ${ }^{19}$ Theories proposed for the pathogenesis of sirenomelia can be categorised into the vascular disruption hypothesis and the caudal embryo damage hypothesis. ${ }^{102235}$ The most likely mechanisms are believed to be a deficiency of the caudal mesoderm as well as a decrease of haemoperfusion in the caudal region and lower extremities of the embryo. ${ }^{1}$ In 1982, Opitz and Gilbert ${ }^{8}$ proposed the concept of midline developmental field. They suggested that in early embryogenesis the midline is a weakly buffered field. Difficulties in the early process of determination because of midline vulnerability may cause both duplication and deficiencies. ${ }^{36}$ Holoprosencephaly, spina bifida, cleft palate, and sirenomelia in this case all belong to the midline anomalies. In 1981, Russsel et al ${ }^{77}$ suggested the term "axial mesodermal dysplasia" to describe a disturbance during early embryogenesis which affects the mesodermal cell migration during the primitive streak period. Combined anomalies in both the cranial and caudal regions have been suggested as examples of axial mesodermal dysplasia. ${ }^{19}$ Our case shows the combination of the most extreme anomalies of the cephalic and caudal regions of the embryo, cebocephaly and sirenomelia. It is related to deficiencies of or damage to both prechordal mesoderm and caudal mesoderm during early embryonic life and can be considered an example of axial mesodermal dysplasia.

The prevalence of cases with a combination of some form of holoprosencephaly with any degree of caudal dysgenesis has been estimated at about 7.9 per million livebirths ${ }^{38}$ which is significantly higher than would be expected by chance. Morichon-Delvallez et $a l^{39}$ concluded that the terminal region of $7 \mathrm{q}$ contains genes implicated in the development of the central nervous system and the caudal region. Lynch $e t$ $a l^{40}$ further concluded that a sacral agenesis gene maps to the HPE3 holoprosencephaly gene region at $7 \mathrm{q} 36$ between $\mathrm{D} 7 \mathrm{~S} 396$ and the telomere, and suggested that genes at $7 q 36$ play a critical role in differentiation of midline mesoderm at both ends of the developing notochord. Our case, a complex of cebocephaly, alobar holoprosencephaly, cleft palate, lumbar spina bifida, sirenomelia, a single umbilical artery, and a normal chromosoma complement, adds examples of overlapping holoprosencephaly and caudal dygenesis.

1 Escobar LF, Weaver DD, Winn J. Sirenomelia sequence. In Buyse ML, ed. Birth defects encyclopedia. Cambridge: Blackwell Scientific Publications, 1990:1541-2.

2 Stocker JT, Heifetz SA. Sirenomelia: a morphological study of 33 cases and review of the literature. Perspect Pediat Pathol 1987;10:7-50.

3 Shenefelt RE. Morphogenesis of malformation in hamsters caused by retinoic acid: relation to dose and stage at treatment. Teratology 1972;5:103-18.

4 Manson JM, Smith CC. Influence of cyclophosphamide an 4-ketocyclophosphamide on mouse limb development. Teratology 1977;15:291-9.

5 Duhamel B. From the mermaid to anal imperforation: the syndrome of caudal regression. Arch Dis Child 1961;36: $152-5$.

6 Twickler D, Budorick N, Pretorius D, et al. Cauda regression versus sirenomelia: sonographic clues. F Ultrasound Med 1993;12:323-30.

7 Battaglia S, Fraccaro M. Anencefalia in sirenide. Fol Hered Pathol 1954;III:197-204.

8 Opitz JM, Gilbert EF. Editorial comment: CNS anomalies and the midline as a "developmental field". $A m \mathcal{F} M e d$ Genet 1982;12:443-55.

9 Schwaibold H, Oehler U, Helpap R, Böhm N. Sirenomelia and anencephaly in one of dizygotic twins. Teratology 1986 34:243-7.

10 Stevenson RE, Jones KL, Phelan MC, et al. Vascular steal the pathogenetic mechanism producing sirenomelia and associated defects of the viscera and soft tissues. Pediatric 1986;78:451-7.

11 Young ID, O'Reilly KM, Kendall CH. Etiological heterogeneity in sirenomelia. Pediatr Pathol 1986;5:31-43.

12 Harris RD, Nyberg DA, Mack LA, Weinberger E. Anorecta atresia: prenatal sonographic diagnosis. $A f R$ 1987;149. $395-400$.

13 Pfeiffer RA, Becker V. Comments on Schwaibold's "sirenomelia and anencephaly in one of dizygotic twins" Teratology 1988;38:497-8.

14 Sirtori M, Ghidini A, Romero R, Hobbins JC. Prenata diagnosis of sirenomelia. F Ultrasound Med 1989;8:83-8.

15 Duncan PA, Shapiro LR, Klein RM. Sacrococcygeal dysgenesis association. Am f Med Genet 1991;41:153-61.

6 Rodriguez JI, Palacios J, Razquin S. Sirenomelia and anencephaly. Am ₹ Med Genet 1991;39:25-7.

17 Gupta R, Gupta M, Gupta S. Sirenomelia bipus (mermaid) with meningocele. Indian 7 Pediatr 1992;59:387-8.

18 Källén B, Castilla EE, Lancaster PAL, et al. The cyclops and the mermaid: an epidemiological study of two types of rare the mermaid: an epidemiological study of

19 Rodriguez II, Palacios J. Craniorachischisis totalis and sirenomelia. Am 7 Med Genet 1992;43:732-6.

20 Duncan PA, Shapiro LR. Interrelationships of the hemifacial microsomia-VATER, VATER, and sirenomelia phenotypes. Am $\mathcal{F}$ Med Genet 1993;47:75-84.

21 Kulkarni ML, Sureshkumar C, Sindhur PS. Sirenomelia with spina bifida. Indian 7 Pediatr 1994;31:51-5.

22 McCoy MC, Chescheir NC, Kuller JA, et al. A fetus with sirenomelia, omphalocele, and meningomyelocele, but normal kidneys. Teratology 1994;50:168-7

23 Roach E, DeMeyer W, Conneally PM, et al. Holoprosencephaly: birth data, genetic and demographic analyses of 30 families. Birth Defects 1977;11:294-313.

24 DeMyer W, Zeman W, Palmer CG. The face predicts the brain: diagnostic significance of median facial anomalies for holoprosencephaly (arhinencephaly). Pediatrics 1963; 34:256-63.

25 Muenke $M$. Holoprosencephaly as a genetic model to study normal craniofacial development. Semin Dev Biol 1994;5: 293-301.

26 Cohen MM Jr, Sulik KK. Perspectives on holoprosencephaly. Part II. Central nervous system, craniofacial anatomy, syndrome commentary, diagnostic approach and experimental studies. F Craniofac Genet Dev Biol 1992;12:196-244.

27 Frézal J, Schinzel A. Report of the committee on clinica disorders, chromosome aberration, and uniparental disomy. Cytogenet Cell Genet 1991;58:986-1052.

28 Muene M. Clinical, cytogenetic and molecular approaches to the genetic heterogeneity of holoprosencephaly. $\mathrm{Am} \mathcal{F}$ to the genetic heterogeneit

29 Cohen MM Jr. Perspectives on holoprosencephaly. Part I. Epidemiology, genetics, and syndromology. Teratology Epidemiology,

30 Cohen MM Jr. An update on the holoprosencephalic disorders. F Pediatr 1982;101:865-9.

31 Nyberg DA, Pretorius DH. Cerebral malformations. In Nyberg DA, Mahony BS, Pretorius DH, eds. Diagnostic 
ultrasound of fetal anomalies. Chicago: Year Book Medical Publishers, 1990:83-145.

32 O'Rahilly R, Müller F. Interpretation of some median anomalies as illustrated by cyclopia and symmelia. Teratology 1989;40:409-21.

33 Norman MG. Central nervous system. In: Dimmick JE Kalousek DK, eds. Developmental pathology of the embryo and fetus. Philadelphia: J B Lippincott, 1992:341-82.

34 Jones KL. Holoprosencephaly sequence. In: Jones KL, ed. Smith's recognizable patterns of human malformation. 4 th ed. Smith's recognizable patterns of human malformation. 4th ed.

35 Langer B, Stoll C, Nicolau R, et al. Sirenomelia and situs inversus: case report and review of the literature. Fetal Diagn Ther 1996;11:79-84
36 Lubinsky MS. Midline developmental "weakness" as a consequence of determinative field properties. Am $\mathcal{F}$ Med Gene Suppl 1987;3:23-8.

37 Russel LJ, Weaver DD, Bull MJ. The axial mesodermal dysplasia. Pediatrics 1981;67:176-82

38 Martinez-Frias ML, Bermejo E, Garćia A, et al. Holoprosencephaly associated with caudal dysgenesis: a clinical-

39 Morichon-Delvallez N, Delezoide AL, Vekemans M. Holoprosencephaly and sacral agenesis in a fetus with a terminal deletion 7q36 $\rightarrow$ 7qter. F Med Genet 1993;30:521-4

40 Lynch SA, Bond PM, Copp AJ, et al. A gene for autosomal dominant sacral agenesis maps to the holoprosencephaly region at $7 \mathrm{q} 36$. Nat Genet $1995 ; 11: 93-5$. 